\title{
PRENATAL PERSONHOOD AND LIFE'S INTRINSIC VALUE: REAPPRAISING DWORKIN ON ABORTION
}

\author{
Kate Greasley* \\ University of Oxford
}

\begin{abstract}
What is at the heart of conflict over abortion? In his celebrated contribution to the topic, Ronald Dworkin argued that disputants in the abortion debate are in fact deeply mistaken about the true terms of their disagreement. Rather than turning on the perennial question of whether or not the fetus is a person, Dworkin claimed that abortion argument is, at bottom, an argument about the intrinsic value of all human life and how it is best respected. More than twenty years after Dworkin put forward his novel thesis, this article reassesses his key claims about the nub of abortion argument, partly in light of subsequent developments in the public abortion conflict. Against Dworkin's revisionist account of the abortion problem, I set out to show that his arguments did not successfully displace the primacy of the personhood question in moral and legal constitutional reasoning about abortion. Nor do they convincingly establish that prenatal personhood is not what contestants in the abortion debate are really arguing about.
\end{abstract}

\section{PERSONHOOD IN ABORTION ARGUMENT}

When we argue about abortion, what should we argue about? In a topic so rife with moral complexity, it can be difficult to gain clarity on just where one's starting point ought to be. Nevertheless, precisely where the locus of debate should reside is not just an interesting inquiry in its own right, but an essential first piece of the puzzle when it comes to thinking through the rights and wrongs of abortion. For many discussants, the argumentative priority of determining whether or not a fetus is what we understand to be a 'person' with strong moral rights is self-evident. Conversely, some serious and influential contributions to the abortion debate have sought to establish that the status of the fetus is neither morally nor legally decisive 
for abortion, and is even rendered redundant by other philosophical considerations, some of which have clear legal analogues.

Speaking plainly, there is more than one way of telling someone that she is asking the wrong question about a contentious subject matter. On the one hand, one could say that her question misfires because the answer to that question will not, in the end, determine anything critical in the discussion, and then go on to illustrate why this is so. On the other hand, one might claim that there is something inherently defective about the question itself - that it asks something that cannot be answered; that it is irrational or unintelligible; that it is not pertinent to the topic under consideration, or that it is not what disputants are truly arguing about. Challenges of both kinds are represented by arguments in abortion debate which seek, in one way or another, to side-line or bypass the personhood question. But challenges of the first kind are, I think, more ubiquitous.

Take the following claim, which we can call the 'Good Samaritan Thesis':

The Good Samaritan Thesis: Abortion is morally permissible in all (or almost all) cases, whether or not the fetus is a person, because gestation is a form of Good Samaritanism - that is, it is a form of supererogatory assistance that no one person could be morally obligated to perform in order to preserve the life of another. Consequently, abortion does not kill the fetus, but only discontinues non-obligatory, life-preserving assistance. 
The Good Samaritan Thesis (GST) claims that abortion is always or almost always permissible, whether the human fetus is a person or not. In effect, it bypasses the personhood question by stating that it is never, or hardly ever, morally obligatory for a woman to carry a pregnancy to term, even to save the life of another person. The most well-known iteration of the Good Samaritan Thesis comes in the way of an analogy drawn by Judith Thomson between pregnancy and a hypothetical situation in which a person is kidnapped by a musical society and forcibly connected to a famous, ailing violinist, whose unique kidney condition means that he needs to be connected to that person's body for the next nine months in order to survive. ${ }^{1}$

Another personhood-bypassing challenge of the same genus is what we might call The Justified Homicide Thesis, which claims the following:

The Justified Homicide Thesis: Abortion is morally permissible in all (or almost all) cases, whether or not the fetus is a person, because it is a recognisable instance of justifiably killing another person.

The Justified Homicide Thesis (JHT) begins by pointing out that our moral and legal principles make exceptions to the general prohibition on killing other persons, for instance in situations of self defence or absolute necessity, where killing one

\footnotetext{
* Stowell Junior Research Fellow in Law, University College, Oxford. This is a working draft. Please do not circulate or quote without permission. Thanks are owed to Leslie Green, Tom Adams, and to two anonymous reviewers for helpful comments.

${ }^{1}$ See Judith Jarvis Thomson, A Defense of Abortion 1 PHIL. \& PUBLIC AFFAIRS 47-66 (1971). There is more to Thomson's argument than GST alone suggests. For a detailed exposition and defence of Thomson's argument, see David Boonin, A DEFENSE OF ABORTION (2003) chapter 4.
} 
person, perhaps, one who is doomed imminently to die anyway, is the only way of saving more endangered human life. ${ }^{2}$ It then claims that if the fetus were a person, abortion would often or always fit those exceptions. JHT differs meaningfully from the GST in analysing abortion as an act of killing, not just the refusal to save. Hence, the two theses construct abortion's permissibility in different ways. On JHT, abortion is an example of justified killing, and on GST, of a justified refusal to save life.

I am not going to assess the merits of the Good Samaritan Thesis or Justified Homicide Thesis. My concern is instead with personhood-bypassing challenges of the second kind, and with one notable example in particular. As I said, challenges of the second kind do not proceed by way of claiming that, in the final analysis, the permissibility of abortion does not depend upon whether the fetus is a person or not. They have an altogether different character, asserting that the personhood question is a fundamentally misconceived starting point for philosophical discussion and, or, legal reasoning about abortion.

Perhaps the most prevalent example of this sort of argument in modern moral philosophy is Ronald Dworkin's intriguing retelling of the abortion debate in

\footnotetext{
${ }^{2}$ Both exceptions are, naturally, subject to proportionality requirements. Actions taken in self defence must be not only necessary to resist the harm threatened by another person but also proportionate to that harm (one may not kill in self defence to avoid sustaining a minor injury). Homicides performed out of necessity are also subject to the proportionality requirement that more of value-namely, human life - is preserved by the killing than is lost by it (and even then, philosophers heavily dispute which side-constraints on necessity killing still apply). I will not be exploring these problems here, but it ought to be acknowledged that, in order to be convincing, the justified homicide thesis would need to show that abortion meets these conditions.
} 
his 1993 book Life's Dominion. ${ }^{3}$ There, Dworkin offered a compelling revision of the abortion problem, which centrally claimed that the traditional debate about prenatal personhood is really only a proxy for an essentially distinct, and more religious-like, kind of conflict about the intrinsic value of human life. Far from being about whether or not the human fetus is truly a person in the philosophical sense, Dworkin argued that the real dispute over abortion revolves around different understandings of human life's intrinsic value, and whether or not abortion insults that value.

Moreover, he argued, failing to correctly diagnose the true nature of the conflict is also liable to induce a second mistaken belief: that abortion disagreement is politically intractable and resistant to principled compromise. Whereas the personhood-centered view of abortion argument leaves, as Dworkin saw it, little scope for principled resolution, once we are only able to understand what abortion argument is really about, a route to principled legal resolution within the context of continuing moral disagreement opens up by means of the doctrine of religious toleration. Dworkin's account thus, as he put it, 'contradicts the pessimistic conclusion that argument is irrelevant and accommodation impossible' which seems so plainly to follow from the traditional view of the debate. ${ }^{4}$

Dworkin's thesis is clearly set apart from other personhood-bypassing accounts of the abortion problem like GST or JHT, and in a way which gives it a certain argumentative priority over them. If he was correct to hypothesise that ${ }^{3}$ RONALD DWORKIN, LIFE'S DOMINION: AN ARGUMENT ABOUT ABORTION AND EUTHANASIA (1993).

${ }_{4}$ ibid 23. 
prenatal personhood is not, in any event, the crux of abortion disagreement, there will be little need to evaluate the other theses I outlined above, both of which set out to show that, despite appearances, whether the fetus is a person does not matter for our analysis of abortion. Consequently, there is good reason to attend to a thesis such as Dworkin's right at the outset of any fresh examination of the rights and wrongs of abortion - at the beginning of the beginning, if you like.

If correct, Dworkin's main claims about abortion argument might also point toward a more profitable pedagogy when engaging in abortion discussion. If, as he surmised, those who believe that the rights and wrongs of abortion turn on prenatal personhood are, in truth, debating something of a wholly different order, then showing those discussants what an acceptable resolution could look like is less a matter of refuting those personhood-centred claims as it is getting them to appreciate their real reasons for making them. Lawyers and constitutional scholars in particular have no doubt found themselves drawn to the promise Dworkin held out for directing legal reasoning about abortion away from the intractable question of what constitutes personhood and into the more familiar territory of religious disagreement and toleration.

Be that as it may, in what follows I set out to show that Dworkin did not manage to displace the philosophical or legal primacy of the personhood issue in abortion argument. In particular, the main putative pay-off of Dworkin's thesisthat a principled political answer can be reached without positing an answer to the personhood question - is not forthcoming. I also contest Dworkin's descriptive claim that prenatal personhood is not, in truth, what contestants in the public abortion 
debate are disputing. My argument for this draws partly from the ascertainable ways in which the shape of that public disagreement has developed since Dworkin made his novel claim and from asking whether those developments bolster or undermine it.

Lastly, although I hold Dworkin's view of the abortion problem to be incorrect, his argument in Life's Dominion is replete with important and instructive insights for anyone approaching abortion from a moral or legal perspective. In the course of underscoring the core weaknesses of Dworkin's contentions, I hope to bring into sharper focus the valuable contributions his thesis makes to abortion argument, which should continue to enrich and direct our reasoning about this perennially (and, even, increasingly) thorny issue.

\section{THE RED HERRING}

Before tracing the detail of Dworkin's account, it is important to clarify the meaning of 'person' in the context of this discussion, especially in relation to the separate descriptor 'human being'. Most moral philosophers distinguish between the classifications 'person' and 'human being', and Dworkin follows convention in this respect. ${ }^{5}$ The ascription 'human being' is a biological categorisation, capturing to any living creature that is genetically a member of the human species. Any human fetus, or, for that matter, newly formed zygote, is at least a human being in the bare sense that it is a form of human life. It is definitely not a frog, or a cat.

\footnotetext{
${ }^{5}$ Dworkin, supra note 3, at 22.
} 
The ascription 'person', on the other hand, refers to those beings which possess a certain kind of moral status, typically elaborated in terms of interests or rights, and yielding a cluster of normative implications concerning how it is morally acceptable to treat such beings. Precisely what all of these normative implications are is a matter of some dispute. At the very least, however, personhood status is taken to entail strict rules about the permissibility of killing creatures in possession of that status. It is never permissible to kill persons, no matter how painlessly, for reasons of convenience or (on most views) even to promote an appreciable level of welfare among other creatures or persons. The same is not generally believed to be true of non-persons.

The analytical distinctness of human beings and persons is apparent from the fact that we can at least conceive of non-human persons: intelligent aliens, angels, perhaps even some non-human animals, can fit our concept of a person without being biologically human. So 'human being' and 'person' do not mean the same thing. It may be true, nevertheless, that all human beings are, necessarily, persons. This would be so if all members of the human species also happened to meet the conditions for personhood, making overlap between the categories one hundred per cent. The analytical separateness of the categories simply means that it is an openand hence, an intelligible—question whether or not this is so.

Embracing this distinction, Dworkin addressed himself to the question whether disagreement about the personhood of the fetus is at the centre of conflict over abortion. In essence, he argued that the personhood issue is little more than a 
red herring in abortion argument, failing to capture the real nature of the conflict, a conflict which he described in the following way:

Opposing armies march down the streets or pack themselves into protests at abortion clinics, court houses, and the White House, screaming at and spitting on and loathing one another. Abortion is tearing America apart. ${ }^{6}$

Argument about abortion is, Dworkin observed, both 'fiercer and politically more important' than any other public battle, including that over euthanasia. ${ }^{7}$ Moreover, when conducted in the traditional terms of argument about prenatal personhood, that conflict also appears to be entirely intractable. This impasse owes substantially to the fact that, as Dworkin says, 'neither side can offer any argument that the other must accept', since different conclusions about the personhood of the fetus are only, ultimately, a matter of 'primitive conviction's. As he wrote:

[T] $]$ here is no biological fact waiting to be discovered or crushing moral analogy waiting to be invented that can dispose of the matter. It is a question of primitive conviction, and the most we can ask of each side is not understanding of the other, or even respect, but just a pale civility, the kind of civility one might show an incomprehensible but dangerous Martian.

On Dworkin's view, those who see the fetus as equivalent to an unborn child from conception and those who view it as no more than a cluster of cells cannot hope

\footnotetext{
${ }^{6}$ Dworkin, supra note 3, at 10.

${ }^{7}$ Ibid at 4.

${ }^{8}$ Ibid at 10.
} 
to persuade each other otherwise by recourse to reason, for their beliefs are not grounded in reasoned argument to begin with, but only in basic intuition. Fundamentally, either we see the fetus as a person or we do not. Neither can discussants who give different answers to the personhood question be expected to harbour much sympathy for the political goals of their antagonists. Those for whom the fetus is metaphysically analogous to a born human being will not be moved by women's rights arguments which, on their view, are blind to the fact that if a fetus is a helpless unborn child 'then permitting abortion is permitting murder, and having an abortion is worse than abandoning an inconvenient infant to die'. ${ }^{9}$ Conversely, those who conceive of a fetus as something hardly different from a body part cannot help viewing the opponents of legal abortion as 'either acting in deep error' or out of bigotry, unreflective religiosity, or vindictiveness towards those whom they regard as fallen women.

As well as lacking any comprehension of or sympathy for one another's positions, Dworkin believed that contestants in the abortion debate conflicted over the question of prenatal personhood have no hope of reaching any principled compromise, for their convictions do not permit that. Those who believe that that the human fetus is a full-fledged person cannot accept legal abortion on the basis of its democratic pedigree any more than dissidents of a genocidal state can accept its atrocities as the will of the masses. On the other hand, those who regard the notion of prenatal personhood as positively laughable cannot be expected to coolly accept the legal prohibition or restriction of abortion, with all of its profound negative

9 ibid 9-10. 
implications for the lives of women, merely because enough of the population believe in a ludicrous proposition. And so Dworkin concludes:

Self-respecting people who give opposite answers to whether the fetus is a person can no more compromise, or agree to live together allowing others to make their own decisions, than people can compromise about slavery or apartheid or rape...

If the disagreement really is that stark, there can be no principled compromise but at best only a sullen and fragile standoff, defined by brute political power. ${ }^{10}$

But Dworkin did not believe we should resign ourselves to this gloomy prognosis. This is because entire personhood-centered picture of the abortion conflict was, to his mind, based on a serious 'intellectual confusion'. ${ }^{11}$ A good indication that the real nub of that disagreement is something other than as first appears comes in the way of what Dworkin called 'signal inconsistencies' in attitudes to abortion on both sides of the divide. Opponents of abortion rights, for instance, commonly make concessions where abortion is necessary to save the life of the pregnant woman, or where pregnancy is the result of incest or rape. Furthermore, many are willing to allow that, although abortion is immoral, it should nevertheless be legally permitted, that it ought not to invoke the same penalties as murder, or that despite their moral objection, they would support their own wife, daughter, or friend if she decided to obtain one.

\footnotetext{
${ }_{10}$ ibid 10 .

11 ibid.
} 
Some 'signal inconsistencies' echo on the "pro-choice" side too. While supporters of abortion rights clearly do not regard abortion as murder, they do frequently characterise it as a kind of a 'cosmic shame', and a 'grave moral decision', not to be undertaken lightly or for trivial reasons, for example because the pregnancy will interfere with a booked holiday. Consequently, they often support some legal restrictions on abortion choice, notwithstanding their beliefs that the fetus is not a person in the philosophical sense.

Dworkin pointed out that on the personhood-centered picture of abortion argument, these results seem 'baffling' ${ }^{12}$. For how could someone who truly believes that abortion kills a person consign the abortion decision to the realm of personal morality, or make concessions where pregnancy is brought about through rape? And why would someone who, say, thinks that abortion is not very different from a tonsillectomy view it as something obviously to be regretted, or the appropriate target of any legal restrictions? The concessions and exceptions commonly made on both sides are, he suggested, flatly inconsistent with the traditional account of the abortion conflict. Regarding the concessions made in particular by moral opponents of abortion, he remarked:

No one can consistently hold that a fetus has a right not to be killed and at the same time hold it wrong for the government to protect that right by the criminal law. The most basic responsibility of government, after all, is to

\footnotetext{
12 ibid 14.
} 
protect the interests of everyone in the community, particularly the interests of those who cannot protect themselves. ${ }^{13}$

However, Dworkin argued, the signal inconsistencies are explicable once the conflict is recast in a different light. Central to a better understanding of abortion disagreement, he claimed, is a distinction between two very different grounds of objection to abortion captured by the interest in 'protecting fetal life'. That interest can, in the one place, refer to what he called the derivative objection to abortion. The derivative objection claims that abortion violates the fetus's right not to be killed, a right which all persons possess. On this understanding, the wrongness of abortion derives from the fetus's individual right to life.

But 'protecting fetal life' can implicate a very different ground of abortion opposition. Dworkin labelled this the detached objection to abortion, because it does not depend on ascribing any rights or interests to the individual fetus. The detached objection claims that all human life has a sacred or, in secular terms, intrinsic value, like the value we might ascribe to a brilliant work of art or find in natural beauty. The objection claims that abortion is wrong not because it violates a fetus's right to life, but because it 'disregards or insults' that intrinsic value. ${ }^{14}$

The detached objection differs critically from the derivative one in that it does not rely in any way on the claim that a fetus is a person or has rights and interests of its own. Nevertheless, Dworkin argued, someone who does not regard the fetus as a

\footnotetext{
13 ibid at 14 .

14. ibid at 11-13.
} 
person may still 'object to abortion just as strenuously as someone who insists it is' if his objection is rooted in detached grounds. ${ }^{15}$ Just as someone might object to turning off the life-support of a patient with an incurable and intolerable illness not because of the belief that death is against her interests, but because the act of killing insults the intrinsic value of human life, so too might a person object to abortion not because she regards the fetus as having an interest in continued life, but because she views the extinguishing of any human life as an unacceptable affront to life's intrinsic value.

Dworkin believed that almost everyone who objects to abortion practice truly objects to it, 'as they might realise after reflection', on the detached rather than the derivative ground. ${ }^{16}$ In other words, the ground of their objection is not their belief in the personhood of the fetus, even if they take it to be thus, but rather their commitment to the more impersonal, intrinsic value of human life, similar in its nature to the value we attribute to beautiful works of art or to endangered animal species whose preservation we take to be a good in itself. Once we understand this, Dworkin claims we can make far better sense of why some people think that abortion is wrong but ought to remain legal, while others think it acceptable, but legitimately regulated. It is perfectly 'consistent', he says, for someone who objects to abortion on detached grounds to hold that it is 'intrinsically wrong' to end a human life, but that the decision whether or not to end that life in utero must be left to the pregnant woman. ${ }^{17}$

\footnotetext{
15 ibid 12 .

${ }_{16}$ ibid 13.

${ }_{17}$ ibid 15.
} 
Moreover, on the detached picture of abortion disagreement, supporters of abortion rights actually share this appreciation of human life's intrinsic value. They too believe that all human life is extremely valuable, and that its destruction is always regrettable - always a 'cosmic shame'. Thus we should not be surprised that defenders of abortion rights are still sobered by the need for abortion and, frequently, support some restrictions.

This all raises a question, however. If disputants on both sides of the debate share a commitment to the intrinsic value of human life, what are they arguing about? Dworkin's answer is that people interpret this value in drastically different ways. He wrote:

How can a shared assumption explain the terrible divisions about abortion that are tearing us apart? The answer, I believe, is that we interpret the idea that human life is intrinsically valuable in different ways, and that the different impulses and convictions expressed in these competing interpretations are very powerful and passionate. ${ }^{18}$

Later in the book, Dworkin offered an account of how different interpretations of life's intrinsic value might sponsor radically different conclusions on the abortion question. More fully, he distinguishes between two different sources of human life's intrinsic value: natural creation and human creative investment. Those who place more stock in natural or biological creation are more likely to conclude

18 ibid 70 . 
that the intrinsic value of human life is always insulted when abortion is carried out. But not everyone will agree that premature death in the womb is the most serious frustration of human life. ${ }^{19}$ Others may believe that performing an abortion is consistent with human life's intrinsic value if it prevents significant human creative investment in the life of the pregnant woman from being squandered. Disagreement about abortion is, in short, disagreement about which 'mode' of life's intrinsic value has the greater moral importance. While conservatives in the abortion debate are likely to think that natural investment in the form of biological life is pre-eminent, liberals more frequently believe that it is a bigger frustration of life's miracle when an adult human being's expectations are disappointed and talents wasted than when a fetus dies before any comparable investment in its life is made. ${ }^{20}$

From all of this, Dworkin draws his significant conclusion about political resolution of the abortion question. Crucially, he argues that disagreement about the meaning and nature of life's intrinsic value has a 'quasi-religious' quality. Our personal interpretations of that value are, he says, 'essentially religious beliefs', relating, as they do, to questions about the meaning of life and death. The end picture is therefore of a conflict which is 'at bottom spiritual'. ${ }^{21}$ But recognising the religious nature of abortion argument has important implications for the possibility of principled compromise. For, once the conflict is translated into these terms-into a matter of religious-like difference- a pathway to principled resolution is laid out by the doctrine of religious toleration. As Dworkin remarked, 'We think that it is a

\footnotetext{
19 ibid at 90 .

${ }^{20}$ See chapter 3 generally, especially 91 .

${ }^{21}$ Dworkin, supra note 3, at 101.
} 
terrible form of tyranny, destructive of moral responsibility, for the community to impose tenets of spiritual faith or conviction on individuals.' ${ }^{22}$ In modern pluralistic democracies, the protection of free exercise of religion therefore undergirds a permissive answer to the question of abortion's legality. Since everyone must be free to express her religious beliefs, for or against abortion, the state cannot coercively remove the abortion option. This is a conclusion which, Dworkin suggests, all those morally opposed to abortion have reason to accept if they are committed to religious toleration.

Finally, when equipped with the 'detached' account, Dworkin believes we can better make sense not only of the moral controversy, but also of the constitutional saga over abortion in the United States - particularly the legal arguments surrounding Roe v Wade, the landmark Supreme Court ruling which recognised, for the first time, that the Constitution granted a fundamental right to termination of pregnancy. ${ }^{23}$ Building on his assimilation of abortion disagreement with religious disagreement, Dworkin argues that freedom of choice about abortion has a clear textual basis in the US Constitution. If, as he claims, beliefs about reproductive freedom are 'essentially religious', then the right to make one's own decisions in such matters can be construed out of the First Amendment, which guarantees the free exercise of religion. Contrary to common assumptions, he suggests that the ongoing constitutional dispute about abortion is not whether individual states have the constitutional power to declare the fetus a person, for, he argued, they plainly do not. Rather, the salient question becomes whether state legislatures have the

\footnotetext{
22 Ibid at 20 .

${ }^{23} 410$ U.S. $113(1973)$.
} 
constitutional power to dictate the intrinsic values which their citizens must respect and how they must respect them. In short, can a state 'impose the majority's conception of the sacred on everyone'? ${ }^{24}$

This account, Dworkin argues, accords far better with the central legal question in Roe v Wade and the basis of scholarly objection to it. As was made evident in Justice Blackmun's majority opinion, it was never conceivable that the Roe court could have declared the fetus a person for the purposes of constitutional protection - or so Dworkin claims. Since all good constitutional lawyers presumably appreciate this, he suggests that the real ground of lawyerly objection to Roe must concern some other part of the ruling, as the wealth of critical focus on the issue of state autonomy over abortion law would suggest. Unlike the personhood issue, the question if and when a government can coerce respect for an intrinsic value, and determine the form that respect must take, is an altogether more complex constitutional question about which we should anticipate serious scholarly disagreement.

\section{III. 'SIGNAL INCONSISTENCIES' AND THE DESCRITPIVE CLAIM}

As we have seen, a key aspect of Dworkin's account is the descriptive claim that prenatal personhood is not, in actual fact, at the root of public controversy over abortion—that it is not what people are arguing about—and that the features of that controversy can be better explained when adopting the 'detached' account of abortion's contestedness. It is with this claim that I wish to start. Scrutinizing it involves asking firstly, whether there is anything about public abortion conflict which stands in need of a special explanation (such as that people are mistaken about

\footnotetext{
24 Ibid 159.
} 
the grounds of their disagreement), and, secondly, whether that explanation cannot be found within the derivative account.

One of Dworkin's main arguments, we saw, was that 'signal inconsistencies' on both sides of the abortion divide are simply a bad fit with the derivative account which casts abortion disagreement as disagreement about prenatal personhood. He did not reach far, however, for alternative explanations of those putative inconsistencies that are more in keeping with a personhood-centred view of abortion conflict, despite the fact that some present themselves. In truth, we should not be at all surprised to find that many people hold ambivalent and even somewhat contradictory views on such a philosophically complex, politicised and emotively charged subject as abortion. Such inconsistencies, which are not special to abortion argument, could owe to any number of things. In the first place, the holders of those views may simply have not thought through their position with much analytical rigour, sheer lack of reflectiveness being, presumably, the most common source of argumentative incoherence. Alternatively, disputants may be led to embrace inconsistent concessions because of emotional or psychological biases, fear of social reproach, or even the need to disingenuously advocate compromise positions for politically strategic reasons.

Of all these possible explanations, strategic necessity strikes one as the most plausible reason why political opponents and supporters of abortion rights often make concessions which look like signal inconsistencies. Ideological opponents of abortion may support exceptions in cases of rape, incest, or grave risk to the pregnant woman's life for a host of pragmatic reasons: to avoid ostracising 
moderates; to focus firepower on the more winnable battles, and so on. If the strategic explanation were correct, we might well expect to see those opponents withdrawing the traditional concessions as and when political climates change and platforms can be radicalised without risking too much of the overall objective: to preserve as much fetal life as possible. The "ironing out" of some signal inconsistencies might be observable from the introduction of new state laws criminalising negligent pregnant behaviour (such as drug taking) which results in harm to or death of the fetus. ${ }^{25}$ The putative inconsistency here is the lack of willingness to subject such women to the same consequences in law they would face for negligently harming their born children. If the fetus is just the same as a child, why should the criminal consequences of causing it harm differ? The more, then, that fetal harm laws are brought into line with laws prohibiting child abuse, , the more this 'inconsistency' begins to look merely like an inauthentic concession of long-standing by opponents of abortion.

Moreover, the derivative account explains perfectly well why ideologically inauthentic concessions such as rape or risk-to-life exceptions could be easily justified for opponents of abortion. If the fetus is indeed the moral equivalent of a

\footnotetext{
${ }^{25}$ See, for example, amendment SB 1391 to Tennessee’s fetal homicide law (Tenn. Code. Ann. \$\$ 3913-107 \& 39-13-214), allowing a woman to be prosecuted for the illegal use of a narcotic while pregnant, if her child is born addicted to or harmed by the narcotic drug and the addiction or harm is a result of her illegal use of a narcotic drug taken while pregnant. A similar bill (SB 599) was introduced into the Oklahoma Senate this year (see http://www.oklegislature.gov/BillInfo.aspx?Bill=sb559). On April $3^{\text {rd }}$ 2015, Indiana resident Purvi Patel became the first pregnant woman found guilty of violating a fetal homicide law, and was sentenced to 20 years in jail. While feticide laws have long existed in many American states, reliance on one to convict a woman of her own fetus's homicide was an unprecedented development.
} 
helpless child, any strategy which promises to gain the most ground in the wider political battle looks rationally defensible, even if it involves advocating disingenuous compromise positions. Theoretical consistency does not count for much when weighed against the value of preventing as much infanticide as possible. Hence, anti-abortion protest which seeks to direct a special degree of moral opprobrium at late abortion will be intelligible on the derivative account if there is any reason to think that it presents the best shot at preventing some fetal deaths (say, because it is easier to mobilise general opposition to late abortion than to early abortion), even if contradicts the protesters' true convictions that all abortion is tantamount to homicide.

On the other side of things, ostensible inconsistencies demonstrated by defenders of abortion rights might equally be explained by a political need to make concessions. Abortion rights campaigners often admit that abortion is always sad or a shame, even when justified. Although this admission does not chime well with the extremely low moral status they accord to the fetus (if nothing of significant moral standing is lost, why such a shame?), it can help to placate moderate sensibilities.

As well as being tenable, mundane explanations like these are perfectly consistent with the pre-eminence of prenatal personhood in abortion disagreement. Rather than offering the explanation that what disputants in the abortion debate say they believe about fetal personhood does not reflect their true beliefs, this explanation suggests that the attitudes which demonstrate signal inconsistencies are themselves inauthentic. 
Aside from scepticism about whether the signal inconsistencies really run deep, it might be thought that Dworkin's appeal to them as evidence that disputants are not really arguing about fetal personhood also relies on a claim that we should hesitate to accept: that no one could be seriously be engaged in a particular theoretical dispute unless his position in that dispute were coherent through and through. Frances Kamm labelled this the 'No Wrong Belief View', that is, the view that no one engaged in abortion debate could hold an inconsistent belief, and, hence, that nothing about the moves in that debate could be explained by sheer inconsistency. ${ }^{26}$ As Kamm argued, there is no basis whatsoever for Dworkin maintaining the complete coherence of public attitudes as a premise in his investigations. By ruling out the possibility that disputants could simply be inconsistent on some points, it seems that Dworkin was jumping too quickly to the conclusion that abortion disagreement must be about something else.

Perhaps Kamm was unfair to attribute such a plainly unreasonable view as the 'No Wrong Belief View' to Dworkin. Rather than suggesting that there are no such things as inconsistent beliefs, we might take Dworkin simply to have been presenting the signal inconsistencies as compelling evidence that the personhood debate is a red herring. Perhaps abortion disagreement is about fetal personhood, notwithstanding those perplexing attitudes. But they are at least good reason to think otherwise. An argument like this would not commit Dworkin to the No Wrong Belief View. Nevertheless, by failing to consider credible alternative

\footnotetext{
${ }^{26}$ Frances Kamm, Abortion and the Value of Life: A Discussion of Life's Dominion, 95 COLUMBIA L.R. (1995).
} 
explanations for some inconsistent positions, Dworkin gave them an unreasonable amount of credence as evidence against the derivative account.

I have suggested that Dworkin may have been wrong to take 'signal inconsistencies' at face value. However, inasmuch as the dichotomous attitudes he was describing are genuinely held by protagonists in the abortion debate, one might even question whether they are necessarily inconsistent with the derivative account. Take, for instance, those abortion protestors who do not, in all respects, seem to equate abortion with murder. One reason they may fail to do so is not because they equivocate about fetal personhood, but because they entertain the possibility (consciously or not) that abortion is an instance of justified homicide, or amounts to the mere failure to be a Good Samaritan. Uncertainty about those questions-in other words, about JHT and GST - is entirely consistent with the belief that the fetus has the same interest in continued life as all born human beings. (As we saw at the beginning, JHT and GST only really become relevant once fetal personhood is presumed).

Someone who regards abortion as something other than murder for either of these reasons would continue to regard it as extremely morally grave and regrettable - something to be avoided as much as possible, as is true of justified killing in self-defence. Still, even on this picture, fetal personhood remains squarely at the centre of abortion disagreement. For, whether they equate abortion with murder or not, the moral and legal issue with abortion comes, for the abortion opponent, from the fact that the death of the fetus is tantamount to the death of a person. It is only this belief which renders abortion so morally problematic for the 
protestor - the kind of act which only stops short of being murder if GST or JHT were true. For defenders of abortion rights who think fetal personhood a ludicrous proposition, abortion does not, to begin with, have such a morally troublesome character.

But defenders of abortion rights may nevertheless acknowledge some value in the fetus or concede that abortion is always, in some measure, a 'cosmic shame', without thereby contradicting their fundamental belief that the fetus is not a person, or belittling the importance of that belief in their wider argument. There is no inconsistency in denying the personhood of the fetus whilst affirming the intrinsic value of all biological human life. To this Dworkin could have no objection, since he suggested that all contributors to abortion debate share a reasonable belief in that intrinsic value, no matter what their views on prenatal personhood. Again, none of this uproots the centrality of fetal personhood, or its denial, for abortion disagreement. The refusal to attribute personhood status to the fetus is still pivotal for the abortion rights advocate's failure to treat abortion as in any respect akin to murder, and hence for her broad support of abortion practice, even if it involves extinguishing something of value.

In sum, then, there may be little about the public abortion conflict that is left inexplicable on the derivative account. But for what it is worth, the derivative account also commands its own fair share of explanatory power, and in some respects outperforms the detached account in this regard. Dworkin duly notes that the abortion conflict is uniquely ferocious as compared with practically all other public disagreements. But this feature accords far better with the derivative than 
with the detached version of the controversy. The escalation to violence, which has punctuated that conflict at times (and again recently) is certainly more explicable when opposition to abortion is understood in terms of the derivative claim that abortion unjustly kills a human child. As a response to the belief that abortion murders children, the shooting of abortionists is at least intelligible, if not justified. Somewhat less so when it is understood as the expression of just one interpretation of the intrinsic value of human life.

Of course, the content of anti-abortion rhetoric has long been of the kind which lends a good deal of support to the derivative view of abortion opposition. Verbal and pictorial protest messages invoke the language and imagery of murder, both implicitly and explicitly drawing a metaphysical equivalence between fetuses and babies. Anticipating this evidence in favour of the derivative view, Dworkin countered that opponents of abortion in fact only employ the rhetoric of murder in order to emphasise their objection based on the sanctity of human life. ${ }^{27}$ Talk of murdering babies simply packs more punch than spiritualistic rhetoric about life's sacred value, although the real basis for opposition was always the latter, he argued. Dworkin's retort has some initial plausibility. But the idea that the anti-abortion movement's assimilation of abortion with murder is empty rhetoric is increasingly

\footnotetext{
27 Dworkin, supra note 3, at 20-21. On page 21, he says: “They declare that abortion is murder, or just as bad as murder, and they insist that human life begins at conception, or that a fetus is a person from the beginning, not because they think a fetus has rights and interests but just to emphasise the depth of their feeling that abortion is wrong because it is the deliberate destruction of the life of a human organism...We must be careful not to be led by emotionally charged descriptions about human life and persons and murder that reveal strong emotions but are not a clear guide to the beliefs that people are emotional about."
} 
difficult to accept, especially in light of the numerous recent attempts at state-level to enact 'personhood amendments' which would redefine constitutional personhood as beginning from conception. ${ }^{28}$ If successful, such amendments would have the effect of outlawing most, if not all, abortion in the given state, in direct contravention of Roe v Wade. Less conspicuously, they would also, presumably, have the effect of prohibiting embryo research and fertility treatments like IVF, which involve embryo wastage, an implication that has not deterred their proponents.

The 'personhood movement' is the most unequivocal demonstration of the anti-abortion movement's depth of commitment to the belief that personhood begins at conception, and indubitably goes far beyond mere rhetoric. But 'personhood amendments' are by no means the only legislative attempts to restrict abortion which have at their heart the suggestion that the fetus is a morally considerable subject, and/or the aim to present it in such a way to those contemplating abortion choice. Measures of the kind include: the expansion of criminal liability for the abuse and neglect of fetuses (The federal Unborn Victims of Violence Act 2004 recognised a 'child in utero' as a potential legal victim if killed or injured during the commission of a number of violent crimes) ${ }^{29}$; abortion restrictions that have relied on the

\footnotetext{
${ }^{28}$ In 2011 alone, 14 state legislatures introduced 26 'personhood' measures. There have been failed attempts to pass such legislation by voter ballot in Colorado, Iowa and Mississippi and North Dakota. See, http://www.prochoiceamerica.org/media/fact-sheets/abortion-personhood.pdf (last accessed September 10, 2015).

${ }^{29}$ See Sara Dubow, OURSElves UNBORN: A HISTORY OF THE FETUS IN MODERN AMERICA (2011), at 139-146. Dubow documents that between 1977 and 1998, at least 200 women in 30 states were prosecuted for crimes of fetal abuse, which included prenatal narcotics exposure crimes.
} 
proposition that 'fetal pain' is experienced during abortion, ${ }^{30}$ and, most recently, mandatory pre-abortion ultrasound scanning and information laws (dubbed, ‘women's right to know' laws), which seek to dissuade women out of abortion choice by requiring medical staff to show them, and, or, describe to them, a sonogram image of their fetus. ${ }^{31}$ Legislative moves such as these draw heavily on the prenatal personhood narrative, either being rationalised by, or attempting to facilitate revelation of, the fact that the fetus has interests similar or equal to that of born human beings.

\footnotetext{
so The Partial-Birth Abortion Ban Act 2003, which prohibited almost absolutely a particularly controversial method of late abortion, cited 'congressional findings' that 'unborn infants' past a certain gestational age are caused pain by the procedure. The constitutionality of the 2003 Act was challenged but upheld in the Supreme Court in Gonzales v Carhart 550 US 124 (2007). In May 2015, the Pain-Capable Unborn Child Protection Act also passed through House of Representatives. The Act seeks to ban all abortion after 20 weeks, explicitly on grounds of fetal pain, apart from in exceptional circumstances. It has yet to pass in the Senate, however. 41 states already have bans on late-term abortions. Since the 2013 Act passed through the House of Representatives, 25 states have considered similar legislation related to fetal pain and/or fetal anesthesia. In Nebraska, a statute banning abortion after 20 weeks on grounds of fetal pain was passed in 2010. Eight states - Arkansas, Georgia, Louisiana, Minnesota, Oklahoma, Alaska, South Dakota, and Texas - have passed laws mandating information on fetal pain in their state issued abortion-counseling literature. (See: https://www.guttmacher.org/statecenter/spibs/spib_PLTA.pdf).
}

${ }^{31}$ The plain objective of such regulations is to provoke revelation of what is thought by their proponents to be a self-evident truth: that the fetus is not just a burgeoning human life, but a fullyinstantiated, rights-bearing person. For a good description of different state versions of the law, see Carol Sanger, Seeing and Believing: Mandatory Ultrasound and the Path to a Protected Choice 56 UCLA L. Rev. 351 (2008). Some states require the provider to show and describe the image; others provide that she may decline to see or look away, though her decision to do so must be recorded. The Texas version of the law requires the practitioner to make the fetus's heart beat audible to the pregnant woman. 
All of this renders the derivative view quite difficult to resist. To be sure, Dworkin may well have responded by insisting that these are yet more red herrings, indicating at most that opponents of abortion are rhetorically committed to the narrative of prenatal personhood, not that they are truly, deeply committed to it. But the wisdom of Occam's Razor should prompt us to reject his alternative explanations in the absence of a clear need for them. Dworkin believed that the rhetoric and ferociousness of the abortion conflict is explained by the fact that disputants are conflicted over an essentially spiritual issue, whilst being mistaken about the true grounds of their disagreement. The far simpler and more obvious explanation is that one side in the conflict really does believe that murder is at stake, while the other side believes the idea so preposterous that bigotry and oppression is all that they can see as left to be marshalled against them.

Lastly, if today's opponents of abortion really are mistaken about their grounds of opposition, then it seems they are quite deeply and irreversibly mistaken. And if the mistake is indeed so deeply entrenched, one may even wonder how worthwhile it is to attempt to reconceive their entire argument for them, rather than to address that objection on its own terms. This pedagogical point also leads on to a further question about what space Dworkin thinks exists between vehemently believing one's grounds of opposition to a practice are $\mathrm{X}$ and one's grounds actually being X. It may be true that, in one way, moral thinking is less the process of changing one's mind as it is discovering what, upon reflection, one already believed to be true. But this is no truer of our beliefs about the moral status of the fetus as it is about anything else. If critics of abortion are firmly enough convinced that their objection lies in the fact that the human fetus is as much a person as the typical, 
adult human being, and that abortion and murder are therefore of a piece, it may well be asked in what sense their 'actual' claims consist in something different.

\section{THE ‘ANTI-PERSONHOOD’ ARGUMENT AND THE CONSTITUTIONAL DISPUTE}

Up to this point, I have been examining the proposition that prenatal personhood is not what public abortion argument is about. But one might well ask why, as philosophers or lawyers, we ought to be interested at all in the nature of public discourse, coherent, rigorous or otherwise. After all, the terms of that discourse do not necessarily bear any relation to the philosophically and legally pertinent issues in abortion. Why should it even matter?

It is clear that Dworkin's claims about the nature of abortion controversy are not meant to be mere descriptions of the public argument. That is, Dworkin was, very clearly, also making the stronger claim that prenatal personhood-or, the 'derivative' question - is not what is philosophically and legally salient in abortion. One important argument for that claim comes in the way of his contention that no one could sensibly regard the fetus as a person with rights and interests of its own, 'in particular an interest in not being destroyed'-from the moment of its conception. ${ }^{32}$ This is because the fetus has never possessed any mental life, something Dworkin sees as an essential pre-requisite of having such interests. Comparing early fetuses to the assemblage of body parts on Dr. Frankenstein's table before the lever is pulled, he insists:

\footnotetext{
${ }^{32}$ Dworkin, supra note 3 , at 15.
} 
...it makes no sense to suppose that something has interests of its own-as distinct from its being important what happens to it—unless it has, or has had, some form of consciousness: some mental as well as physical life. ${ }^{33}$

He may, of course, be right about that. But as Frances Kamm pointed out, Dworkin's assertion here looks less to be evidence of the irrelevancy of prenatal personhood in abortion as it is an 'anti-personhood argument'. ${ }^{44}$ The fact that Dworkin himself finds the notion of prenatal personhood quite implausible (a claim which, apart from asserting the necessity of mental states for interests, he does not accompany with a great deal of argument ${ }^{35}$ ) does not go to show that the derivative view of the abortion problem is false. This is because the primacy of the derivative question in our philosophical inquiries about abortion can still be demonstrated simply by attending to the fact that were the fetus a person, abortion would seem to be (absent justification) tantamount to murder. Dworkin cannot therefore dismiss the philosophical importance of the derivative question only by arguing that no sensible discussant would classify the fetus as a person.

Nor does the anti-personhood argument further Dworkin's descriptive claim that the personhood issue does not form the content of the claims on either side of the abortion conflict. In underlining the ludicrousness of the idea that a being

\footnotetext{
${ }^{33}$ Ibid at 16.

${ }^{34}$ Kamm, supra note 26, at 167. My emphasis.

${ }^{35}$ Don Marquis commented that Dworkin accompanied this 'crucial assertion'- that interests require some form of consciousness- 'with no argument whatsoever', even though 'his analysis of the ethics of abortion collapses if it is untrue' (see Don Marquis, Life, Death and Dworkin (Review Essay), 22 PHILOSOPHY \& SOCIAL CRITICISM 127-131 (1996).
} 
lacking in mental states could be a rights-bearing person, Dworkin sought to provide yet more evidence that disputants must be arguing about something else. It is, however, a strange kind of evidence which just impresses the argument of one side of the personhood debate. The strength of Dworkin's own conviction that personhood must supervene on particular mental states does not make it implausible, or any less likely, that many understand personhood's conditions to be different, and object to abortion for precisely that reason.

But Dworkin's claims about the true nature of the abortion problem were not restricted to the moral realm. Alongside his arguments about the moral controversy, Dworkin made the parallel claim that the detached, rather than the derivative, question is what lies at the heart of constitutional disagreement about abortion. He argued that the main features of that disagreement-and especially, the nature of scholarly objection to Roev Wade—reflect the detached dispute far more so than the derivative. In short, different views about prenatal personhood are not what explain disagreement about abortion's constitutionality.

One reason for this claim stems from Dworkin's observation of a particular 'signal inconsistency' inhering in scholarly objections to the Roe v Wade decision, if dispute about prenatal personhood is thought to be the crux of the constitutional tussle. In the wake of Roe, scholars critical of the decision largely contested the ruling not because of the Supreme Court's refusal to recognise the fetus as a person under the US Constitution, a conclusion that Dworkin argued was legally inevitable, but because of their belief that the Court should have left individual states free to determine their own abortion laws as they always had done. As Dworkin explained, 
however, this core objection to Roe, based on the value of state autonomy, is, in a significant way, incompatible with the view that the fetus is a person for the purposes of the Constitution, and that the Roe court erred in determining differently. This is because, he suggested, those whose objection to Roe sprang from the belief that the fetus is a person under the Constitution would not be able to argue, as they did, that the Court should have left states free to prohibit or permit abortion as they choose. For, if the fetus is a constitutional person, 'then states not only may forbid abortion but in some circumstances must do so' ${ }^{36}$ Put differently, if fetuses are indeed owed equal protection under the $14^{\text {th }}$ Amendment, then states cannot be left free to choose the abortion laws they wish, since permissive abortion laws will breach fetuses' constitutional rights. From this Dworkin concluded that academic opponents of Roe who have directed their scholarly objection at the issue of state autonomy over abortion law cannot, at the same time, object to Roe on the ground that the fetus is a constitutional person.

This tension dissipates, however, as soon as soon as the constitutional dispute is translated into detached terms, or so Dworkin argues. On this view, scholars objecting to Roe do not truly do so on the ground that the fetus is owed constitutional personhood, but because of the belief that states may have 'a compelling detached reason for prohibiting abortion': to protect the inviolability of human life. Those scholars who disputed Roe in defence of state autonomy could presumably claim that states ought to be free to legislate to protect fetal life if they so chose, but not that the Constitution requires them to forbid abortion, which would follow from a recognition of fetal constitutional personhood. On this understanding,

${ }^{36}$ Dworkin, supra note 3 , at 16. 
the core legal question then becomes whether governments should attempt to dictate to its citizens what intrinsic values they will recognise, and why, and how', including what this means for abortion. ${ }^{37}$ In other words, should states be permitted to impose the majority's conception of the sacred on everyone? This view of the core legal dispute accords quite well with the prominence of the state autonomy issue in academic argument, with those objecting to Roe believing that individual states ought to be allowed to dictate to their citizens what the intrinsic vale of human life means vis-à-vis abortion, and those supporting Roe believing that they cannot.

Dworkin's detached reading of the constitutional issue is bolstered by his claim that there simply is no legally respectable objection to the Roe Court's conclusion that the fetus lacked the status of a person under the Constitution. At the time Roe was decided, the fetus had never been recognised as a constitutional person under US law. Texas, the state whose abortion legislation was under scrutiny, argued before the court that the fetus was indeed a person within the meaning of the 14th Amendment. Justice Blackmun firmly held that the law had never treated fetuses as constitutional persons and could not expand the category now. This was despite his acknowledgment that, had the fetus held the status of a person under the 14, $4^{\text {th }}$ Amendment, it would be entitled to equal protection and abortion would be rendered largely unconstitutional. Dworkin accepted this conditional claim about what would follow if the fetus were granted constitutional personhood, but emphatically endorsed Roe's ruling that it lacked such protected status. In fact, he regarded it as legally unthinkable that the Court could have come to any other decision on this point. As he wrote, 'almost all responsible lawyers' agree that Justice

\footnotetext{
37 Ibid at 117 .
} 
Blackmun's opinion on the personhood question was correct, since there was no precedent in US law for the proposition that the fetus is a person, and the Supreme Court surely lacked the power to recognise new kinds of constitutional persons. ${ }^{38}$

Dworkin concludes from this there is no credible ground of scholarly objection to the Roe Court's conclusion on the personhood question. If Roe $v$ Wade and its main successor case, Planned Parenthood $v$ Casey, 39 were bad law, this could not be because of any legal mistake about fetal personhood.

Dworkin's exposition of the tension between the claim that the fetus is owed constitutional personhood and that states ought to be left free to determine their own abortion laws is incisive for constitutional scholars. As between fetal constitutional personhood and state autonomy over abortion, it is, apparently, one or the other; state freedom to grant abortion rights cannot be tolerated if the fetus is a person. Still, it does not necessarily follow that Dworkin is correct about the main question for the constitutionality of abortion.

To start with, lawyers who disagree with Roe because they view the fetus so plainly as a person in the philosophical sense are not barred from objecting to Roe on different legal grounds. Even those who concede the legal inevitability of that part of Roe's ruling can have good reason to challenge the decision on alternative grounds, especially if those grounds present the more promising routes to reversing the decision and curtailing abortion rights. In conservative states at least, a legal defeat

\footnotetext{
38 Ibid at 110 .

39 505 U.S. 833 (1992).
} 
of Roe based on the Supreme Court's misappropriation of state autonomy would still yield the desired result: the prohibition of abortion. And if, as those who hold the derivative objection believe, abortion unjustly kills persons, any effective legal argument against the constitutional right to a termination is presumably as good as any other.

Next, scholars objecting to Roe on state autonomy grounds need not embrace incoherence if they are also committed to the normative claim that, being a person (as they see it) in the moral sense, a fetus ought to have its personhood recognised by the Constitution. A legal case in favour of states retaining autonomy to permit or prohibit abortion as they see fit could begin by granting, for the sake of argument, Roe's conclusion on the personhood issue. In other words, a lawyer might argue that once it is accepted that the fetus lacks constitutional status, the correct legal conclusion is that states should be free to determine their own abortion laws. Correct or not, there is nothing inconsistent about this position, which in no way commits its proponents to endorsing the Roe majority's refusal to extend constitutional personhood to the fetus.

This said, a considerable amount of contemporary objection to Roe does explicitly target its ruling on fetal personhood, as the 'personhood amendment' movement demonstrates. ${ }^{40}$ This brings us to Dworkin's stronger claim that the fetus's personhood status is simply not constitutionally salient. As seen, this claim

\footnotetext{
${ }^{40}$ The adoption of a constitutional amendment to grant the fetus personhood status under the $14^{\text {th }}$ Amendment is currently a core tenet of the Republican National Committee's platform on abortion. See, https://www.gop.com/platform/we-the-people/.
} 
rests in what Dworkin perceives as the undeniability of Roe's conclusion on fetal personhood as a question of law. Since there was no precedent for recognising the fetus as a subject of protection under the $14^{\text {th }}$ Amendment, Dworkin argued that a contrary ruling would have been legally unsupportable. He did, however, acknowledge the fact that the Supreme Court has been known to upend conventional understandings of the Constitution on questions as fundamental as this - citing Brown v Topeka Board of Education ${ }^{41}$ as a standout example. What, then, of the possibility that the Supreme Court might have broken with tradition and simply declared the fetus a constitutional person because it regarded it as a person in the philosophical sense?

Dworkin responds to this by restating that the idea of fetal personhood is scarcely intelligible and few people believe it'. ${ }^{42}$ Yet this is only a reconfiguration of the 'anti-personhood' argument. Dworkin may think the idea that fetuses are persons unintelligible, but certainly more than a few people believe it. For those who do, the Roe majority's refusal to extend equal constitutional status to the fetus was surely its greatest error. The upshot is that Dworkin fails to dislodge the primary significance of the derivative question for the constitutionality of abortion. Even if, as Dworkin claimed, little of the academic criticism surrounding Roe concerned the personhood ruling, he still seems to accept two key propositions:

1. A finding of constitutional personhood on behalf of the fetus would affect the constitutionality of abortion, and

\footnotetext{
41347 U.S. 483.

${ }^{42}$ Dworkin, supra note 3, at 112.
} 
2. A correct belief in the philosophical personhood of the fetus is a reason for granting it constitutional personhood, even if this breaks with constitutional tradition.

It follows from these joint propositions that whether or not the fetus is correctly regarded as a person in the philosophical sense in indeed integral for the constitutional argument about abortion. Consequently, Dworkin cannot use the 'anti-personhood' argument to dismiss the constitutional primacy of the derivative question, especially to those who do, in fact, defend the philosophical personhood of the fetus.

\section{INTRACTABILITY AND PRINCIPLED COMPROMISE}

As was seen, Dworkin believed that if the derivative view of abortion conflict is correct, then that conflict is inherently intractable and resistant to principled compromise. Misunderstanding the real root of the disagreement therefore has serious consequences for resolving abortion politically. As he adumbrated:

the confusion between the two kinds of objection [derivative and detached] has poisoned public controversy about abortion and made it more confrontational and less open to argument and accommodation than it should be. ${ }^{43}$

Dworkin's pessimistic characterization of the derivative debate stemmed from his claim that what is believed about the metaphysical status of the fetus can only

43 Ibid at 13. 
ever be a matter of 'primitive conviction'. The personhood question is a philosophical dead-end in the abortion debate partly because it cannot sponsor any reasoned exchanges. He makes the point that it is not even clear in theory what it would take for all participants in that debate to be persuaded one way or the other. As he puts it, 'there is no biological fact waiting to be discovered or crushing moral analogy waiting to be invented that can dispose of the matter'. ${ }^{44}$ It is not just that there have been no winning shots in the personhood debate; we cannot even be sure of what one would look like. ${ }^{45}$

Insofar as philosophical tractability is thought to be a virtue of any account of the abortion problem, we should of course ask whether the detached view fares any better in that regard. If, as Dworkin argued, the basis of disagreement has in fact been the sanctity of human life all along, the very fact that the disagreement shows no signs of abating might be offered up as evidence in itself that the detached dispute is no more tractable than the derivative one. This should not be such a surprise. If Dworkin is correct that the nature of abortion dispute is 'essentially religious',

\footnotetext{
${ }^{44}$ ibid at 10 .

${ }_{55}$ This point can be reinforced merely by considering the multitude of hypothetical revelations about the fetus which would not obviously end argument about whether it meets the conditions for personhood. We might suppose it is discovered that the human fetus of a certain gestational age remembers things, feels pain, and has rudimentary desires. There will still be those who claim that independent biological existence is a necessary condition for personhood. Likewise, we could image scientists assuring us that a fetus possesses no conscious life whatsoever, no matter how rudimentary, before birth. For many, this will make no difference to the fetus's personhood status, which owes to its membership in the human species, not any exercisable psychological capacity. There is, I think, no plain fact about the fetus which would end argument about prenatal personhood one way or the other. This is, of course, entirely what we should expect of a dispute which is fundamentally moral (having to do with the value that ought to be ascribed to creatures possessing this or that quality) and not scientific.
} 
intractability is precisely what one would expect. It is strange if Dworkin imagined that a conflict rooted in religious-like commitments would foster more reasoned exchanges, or be any more philosophically soluble, than argument about the conditions for personhood. ${ }^{46}$ At the same time, if intractability really were a feature only of the derivative question, then the continuation of profound disagreement would count as good evidence for the derivative account.

It is not at all clear, then, that of the two kinds of disagreement, the derivative one is uniquely philosophically intractable. One might also think there is some measure of tension between Dworkin's claims that the derivative question is not amenable to reasoned argument and his own reasoned argument against fetal personhood, based on their lack of mental states and, hence, interests. Let us put these complaints to one side, however, and consider Dworkin's main argument about the political resolution of the abortion dispute. This is that if he is correct that abortion disagreement is 'essentially religious' disagreement, as the detached account suggests, a settled constitutional basis for compromise is provided by the doctrine of religious freedom. In practical terms, he argued, this means that a permissive stance on abortion practice is constitutionally required. The First Amendment right to free exercise of religion protects the equal right of all citizens to follow their convictions on 'profoundly spiritual matters', with the result that states may not impose an official line on the abortion question. ${ }^{47}$ This constitutional

\footnotetext{
${ }^{46}$ Perhaps all moral questions are intractable past a point - the point at which their answer depends on far more deep-seated philosophical commitments, argument about which is bound to be interminable.

${ }_{47}$ Dworkin, supra note 3, at 165.
} 
basis for the abortion right is, he argued, one which all those committed to the free exercise of religion have a reason to accept, even if they continue to disagree, 'religiously', about the morality of abortion.

Some will no doubt quibble with Dworkin's suggestion that abortion beliefs can be assimilated into essentially religious ones. ${ }^{48}$ But let us assume that he is right about that. The next question is whether it follows, as Dworkin seems to believe, that the derivative issue is not pertinent to the constitutionality of abortion. Dworkin is guilty of a fundamental oversight regarding the limits of the doctrine of religious toleration if he believes that it can ground the abortion right irrespective of one's answer to the derivative question. His mistake is in supposing that as soon as religious beliefs are at issue, the derivative worry about causing harm to persons ceases to be relevant for the legal resolution of disputes. The plain falsity of this is apparent when bringing to mind any exercise of religious belief that entails bodily harm to individuals we are certain are persons. Liberal democracies do not, for example, extend tolerance to practices of ritual child sacrifice, slavery, or female genital mutilation if and when those who practice them do so as a matter of religious conviction. The doctrine of religious toleration has clear limits: toleration ends where the infringement of people's rights begins. And the infringement of the right to life is the clearest red line of all.

\footnotetext{
${ }^{48}$ The definition of religious belief to which Dworkin appeals seems, rightly, to look to the content of the belief rather than the fervency with which it is held, although the content requirement itself is a fairly loose one, capturing everything that, he says, 'touches on' the 'ultimate purpose and value of human life itself. One might think that abortion beliefs are often religious in a different way, which is that they are mandated by the religious institutions to which many people are affiliated (as is surely true of American evangelicals, Catholics, Irish protestants, and so on).
} 
Dworkin is wrong, therefore, if he believes that applying the doctrine of religious toleration to abortion does not rest on derivative grounds, or presuppose them. If the fetus were a person, as one side of the abortion debate insists, the right to abortion could not be defended using the religious freedoms of those that take the opposite view, for the doctrine of religious toleration does not protect homicide. Indeed, if the religious nature of abortion beliefs mandates toleration of their expression even where that entails harm to persons, we would have to ask why Dworkin's principle does not protect the killers of abortion doctors. Consequently, by even appealing to the doctrine of religious toleration as a basis for political resolution, Dworkin presupposes a particular answer to the philosophical question of prenatal personhood. Toleration of abortion choice, even as a mode of religious expression, cannot be justified if the fetus is a person. And this consideration propels the derivative question right back to the forefront of our reasoning about abortion.

\section{ARGUING ABOUT PERSONHOOD}

But what if the notion of fetal personhood really does strike one, as it did Dworkin, as 'scarcely intelligible'? In the eyes of some, the assignation of personhood to fetuses is wrong not merely in that it is a miscalculation-because it is, in the end, false. It is wrong for being conceptually incoherent. On this thinking, our shared concept of a person can no more admit human fetuses within its boundaries than it can admit rocks or trees or insects. To be sure, someone might protest that a rock, a tree or an insect is in fact a person, and that we have always been mistaken in thinking otherwise. To such a protest, there may be little to say except that the person making it does not grasp the concept of a person if she is willing to make 
such claims. If anything is true about persons, it is that a rock cannot be one. A dispute about whether or not rocks in fact are persons could not, therefore, be an argument about the borderlines of the concept, but only an instance of discussants failing to discuss the same concept at all.

Dworkin seemed to view the fetal personhood debate in somewhat similar terms. As Don Marquis commented, 'for Dworkin, apparently, the central claim needed to support the conclusions of those opposed to abortion hardly rises to the dignity of being false'. ${ }^{99}$ In Dworkin's view, anyone who does not understand that conscious states are necessary features of a person simply lacks any comprehension of what persons most basically are. It is also possible to see from this just how Dworkin's 'anti-personhood' argument undergirds his descriptive claims concerning what abortion argument is really all about. If the notion of fetal personhood is not even comprehensible, then it is hardly likely that abortion opponents believe it. Far more likely that abortion discussants are just employing different concepts and talking past each other.

If Dworkin was right about the conceptual absurdity of fetal personhood, then the derivative issue would seem to lose much of its argumentative relevance for abortion. It would be pre-eminent only in the sense that something nobody believes, and which is 'scarcely intelligible', would have serious implications for the legal and moral status of abortion if it happened to be true. This is surely irrelevance of an important kind. Likewise, if insects happened to be persons, this would have

\footnotetext{
${ }^{49}$ Marquis (1996) at 129.
} 
profound implications for the permissibility of pesticide use. Yet this does not entail that the permissibility of pesticide use hinges, fundamentally, on the question of 'insect personhood' (as opposed to the possible ecological harms of its use), for we know that proposition to be plainly false.

I have not wanted to commit myself here to any substantive view about fetal personhood, taking as my target instead the prior question whether the personhood issue is critical for our moral and legal calculations about abortion. One thing Dworkin's enterprise may have revealed is just how difficult it is to form a judgment on this prior question that is hygienically separate from one's beliefs about the conditions of personhood. If fetal personhood is an unintelligible proposition, the personhood question will hardly seem to have a place in explaining the moral complexity of abortion, if indeed any complexity then remains.

But I believe Dworkin overstated the case if he relegated the notion of fetal personhood to the realm of the conceptually incoherent. The human fetus is distinctly unlike rocks, trees and insects in ways that render ascriptions of personhood more intelligible with respect to them. Without wishing to expand much on those features here, three in particular stand out. The first is the human fetus's biological membership in a species whose typical adult members are unquestionably persons. The second is its biological continuity with developed (and hence, paradigmatically person-like) human beings. The third is the historical errors of denying personhood status to some groups of biologically human beings. In every other case in history when some biological human beings have been denied status, or 
full status, as persons, the denial has been a terrible moral atrocity. If we are right to take this attitude with fetuses, it will be the first and only time.

These might all be fielded as tentative reasons for taking the suggestion of fetal personhood more seriously than the notion that rocks or trees or insects might be persons. Moreover, this shadow of a doubt clearly looms larger at the margins of gestation and birth, where the physiological differences between the fetus and personhood-possessing neonates are much reduced. ${ }^{50}$ And insofar as there is reason to take seriously the proposition that fetuses could be persons, the hypothetical implications of an affirmative answer make it the first port of call in a serious discussion about abortion.

What, though, if the signal inconsistencies Dworkin illuminated hold independent rational appeal for us? What is someone to make of the derivative question if she finds merit in the notion that having an abortion is not just like cutting one's hair or having a tonsillectomy, whilst being, nonetheless, a far cry from murder? For Dworkin, as we have seen, these cross-cutting judgements could only go to show that arguing about abortion by way of debating prenatal personhood is a fruitless. But perhaps he was too hasty in ruling out the possibility that a richer conception of personhood will somehow account for intuitions such as these. Where

\footnotetext{
${ }^{50} \mathrm{I}$ do not mean to assume here that neonates possess philosophical personhood whereas late-term fetuses do not, or that birth is morally significant for personhood status - questions about which there has been a good deal of writing. My point is only that the typical assignation of personhood to neonates gives reason to seriously examine the moral status of late fetuses, which closely resemble neonates in physiological development (although there are also marked physiological differences) and are closely biologically continuous with them.
} 
Dworkin saw inconsistency, he might instead have seen ambivalence or nuance. He might have seen discussants grasping at an intermediate category of being - a being that lacks the full status of a person, but is not entirely without some of its interests and value.

Interestingly, by underscoring putative inconsistencies in hostile and favourable attitudes to abortion, Dworkin appears to have demonstrated at least one way to reason fruitfully about fetal personhood. In pointing out the surface inconsistencies in each other's positions, contestants in the debate can appeal to one another through more than just 'primitive conviction'. There is clear argumentative merit in pointing out, for instance, that someone's failure to treat abortion as in all respects like murder, or as equal to infanticide, challenges her commitment to the belief that a fetus is a person in the fullest sense. Equally, asking someone who flatly denies fetal personhood what salient differences hold between late term fetuses and neonates can surely form part of a potentially persuasive argument. Whether they are ultimately winning or not, these are reasoned forms of engagement that seek to change minds by drawing on discussants' own judgements and distinctions, and attempting to reveal inconsistencies within them (the standard methodology of moral philosophy).

Still, if fetal personhood really is the touchstone of abortion disagreement, the question might linger as to why contestants in the abortion debate do not explicitly engage one another even more on that front than they already do. As I suggested earlier, discussants' motivations for framing their position as they do may be multifarious, but one compelling explanation for the lack of a developed public 
dialogue about the personhood question is that defenders of abortion rights in particular often fail to make their denial of fetal personhood explicit, or fully appreciate its importance in the wider debate. Failure to foreground this important premise might be due to more than one thing: a belief that the fetus's sub-person status is so self-evident as to not warrant pointing out, or the inability to see any way of arguing for it that does not rely on its self-evidentiary quality. Either way, the result is a failure to meet the core tenet of abortion opposition head-on. Mary Anne Warren stated the problem this way:

Because pro-abortionists have never adequately come to grips with the conceptual issues surrounding abortion, most if not all if the arguments they advance in opposition to laws restricting access to abortion fail to refute or even weaken the traditional antiabortion argument, i.e. that a fetus is a human being [in the "moral sense"], and therefore abortion is murder. ${ }^{51}$

Nor did Warren think that supporters of abortion rights should settle for a legal answer which views the terminating act as, albeit justified, 'comparable to killing in self defence', when the basis of their own conviction is, quite differently, 'the realisation that a fetus is not a person and thus does not have a full-fledged right to life'. ${ }^{52}$ This frequent neglect of what is really a foundational premise in the abortion rights argument can go a long way towards explaining why it may seem as if the two sides must be disagreeing about something else.

\footnotetext{
${ }^{51}$ Mary Ann Warren, On the Moral and Legal Status of Abortion, 57 THE MONIST 43-61 (1973), at 43.

52 Ibid at 52 .
} 
On Dworkin's view, the 'quasi-religious' nature of our beliefs in matters of life and death places the abortion issue firmly in the realm of private morality, and out of reach of the law's coercive power, albeit not necessarily its non-coercive influence. In no context, however, is the fundamental right to life of born human beings subordinated to religious beliefs in this same way. Homicide crimes are never constructed so as to tolerate someone's acting on such a belief. 'Honour killings', for instance, cannot be shielded by a principle of religious toleration, though they are, in one way, the expression of a view about life's intrinsic value and what does and does not insult it. If the situation is different for human fetuses, this can only be because they are earmarked from the outset as differently morally positioned. If a fetus is metaphysically on a par with born humans, then something very different from tolerance towards diverse interpretations of the sanctity of life will be required to explain the moral permissibility of abortion.

It may be asked whether, in the end, what Dworkin called the 'detached' inquiry captures questions that are truly morally distinct from the derivative one. On one rendering, the question at the centre of the detached dispute is simply when, in the lifespan of a biologically human organism, that organism comes to possess the attributes which grant it strong moral protection, most pointedly protection against being killed in the cause of salvaging creative investment in the lives of others. Is this just the personhood question in another guise? However the substantive conditions for personhood are filled out, the detached view still hypothesises a point in the development of human life when terminating that life for anything other than the limited justifications we would accept for the killing of fully developed adult 
human beings is an impermissible affront to the sanctity of human life, the pertinent question then being just what it is that ushers in this new metaphysical status.

To the extent that the detached and derivative questions are really two sides of the same coin, Dworkin's reflections on the relative importance of natural and creative investment in human life introduced a new and valuable point of discussion: is biological humanity or human creative effort in a life more constitutive of moral status? In different ways, moral philosophers have subsequently taken up this discussion with zeal. ${ }^{53}$ Far from consigning the personhood inquiry to irrelevancy, however, these further questions only present particular, and potentially illuminating, ways of thinking about what constitutes a person.

\footnotetext{
${ }_{53}$ See, in particular, Don Marquis, Why Abortion is Immoral, JOURNAL OF PHILOSOPHY 183-202, (1989) and Jeff McMahan, THE ETHICS OF KILLING: PROBLEMS AT THE MARGINS OF LIFE, (2003).
} 